\title{
WATER REMEDIATION OF CHROMIUM (VI) BASED ON SULPHURIC ACID GENERATED BIO-CHAR FROM STEMS OF Averrhoa carambola PLANT AS ADSORBENT
}

\author{
Malireddy Venkata Sai Mohan Reddy, Gullapalli Sreelatha, Doddi Kishore \\ Babu, Wondwosen Kebede Biftu and Kunta Ravindhranath* \\ Department of Chemistry, K L University, Green Fields, Vaddeswaram-522 502, \\ Guntur Dt., A.P., India \\ *E-mail: ravindhranath.kunta@gmail.com
}

\begin{abstract}
Sulphuric acid generated bio-char from stems of Averrhoa carambola plant (SBCSAC) is investigated for its Cr (VI) adsorption. At $\mathrm{pH}: 2$, complete removal of $\mathrm{Cr}(\mathrm{VI})$ from $25 \mathrm{ppm} \mathrm{Cr}(\mathrm{VI})$ solution is achieved with one hour equilibration with $0.1 \mathrm{~g} / 100 \mathrm{ml}$ of SBCSAC at room temperature. The adsorption capacity of SBCSAC is $40 \mathrm{mg} / \mathrm{g}$. It is higher than many sorbents reported. The interference of co-cations and co-anions is limited. SBCSAC can be regenerated and reused for four cycles with little loss of capacity. $\mathrm{Cr}(\mathrm{VI})$ in sewage samples of industries are removed completely using SBCSAC.
\end{abstract}

Key Words: Averrhoa carambola, Adsorbent, Cr(VI), Applications.

(C) RASĀYAN. All rights reserved

\section{INTRODUCTION}

The contamination of water bodies with the Chromium species is one of the major environmental issues. ${ }^{1-}$ ${ }^{4}$ Chromium exists in trivalent and hexavalent states in stable waters. ${ }^{1}$ Of the two oxidation states, the hexavalent state is more toxic. ${ }^{1,3}$ As per EPA, the maximum permissible limit of $\mathrm{Cr}$ species is $0.05 \mathrm{ppm}$ in potable water; $0.1 \mathrm{ppm}$ for surface or groundwater; and $0.25 \mathrm{ppm}$ for industrial water. ${ }^{1-3}$ The harmful effects of these Chromium species include gastric problems, malfunctioning of liver and kidney and it leads to lung cancer. ${ }^{4}$

The main sources of Chromium contamination are the untreated or ill-treated discharges from industries. ${ }^{1-}$ ${ }^{6}$ The effluents from leather tanning, textile-printing works, ink manufacturing, chrome plating industries, nuclear energy plants and leaches of fly ashes from thermal power stations, are some of the many sources of Cr-contamination. ${ }^{1-7}$ Chromium species get accumulated in water bodies due to their non-biodegradable nature and further, their involvement in the process of bio-amplification. This endangers aquatic life. Hence, the removal of Chromium from water is a major concern.

Chemical reduction and precipitation ${ }^{8-11}$, flocculation ${ }^{9}$, electroplating-electrolysis ${ }^{12,13}$, ion exchange ${ }^{14}$ and nano-filtration $^{15}$, are some of the conventional methods employed for Cr-removal. The methods based on precipitation are not effective at low $\mathrm{Cr}$-concentrations while the other methods are non-economical and need more technical support and are not adoptable in large-scale treatments. In this context, adsorption methods based on bio-adsorbents obtained from plant materials are attracting the researchers. ${ }^{16-30}$ These sorbents are proving to be effective and the methodology involved is simple and the sorbents are derived from plant materials that are abundantly available and renewable.

Bioaccumulation $^{16}$, activated carbons ${ }^{17-20}$, coconut fiber ${ }^{21}$, eucalyptus bark ${ }^{22}$, maple sawdust ${ }^{23}$, Hevea brasilinesis sawdust activated carbon ${ }^{24}$, waste tea leaves and rice husk silica ${ }^{25}$ are investigated for their effectiveness in Cr-removal. Further, barks of Nerium odorum ${ }^{26}$, stems of Calotropis zygantia ${ }^{26}$, barks of Ziziphus Mauritiana Plant $^{27}$, Spent coffee grounds ${ }^{3}$, Phoenix sylvestris seed powder ${ }^{28}$, leaves of Salvadora persico and Caesalpinia bonduc plants ${ }^{29}$ and Chenopodium album and Eclipta prostrate plant materials ${ }^{30}$, are investigated for their $\mathrm{Cr}$-sorption nature. 
RASĀYAN $J$. Chem.

Vol. 13 | No. 4 |2490-2497| October - December | 2020

These bio-methods based on plant materials are simple and effective. They depend upon materials that are renewable, eco-friendly and cheap. The main problem in this aspect of research is the identification of biomaterials that have an affinity towards pollutants.

Our initial investigations reveal the bio-char obtained from Averrhoa carambola plant stems by digesting in Conc. Sulphuric acid, is effective as an adsorbent in the removal of hexavalent chromium from water. In the present work, the absorptivity of this ' $\mathrm{H}_{2} \mathrm{SO}_{4}$-generated bio-char' towards Chromium (VI), has been investigated concerning different physicochemical characteristics for optimizing the extraction conditions for the maximum Cr-removal. The developed method has been applied to real polluted waters.

\section{Adsorbent Synthesis}

\section{EXPERIMENTAL}

Different plant materials and their bio-chars produced by different methods were investigated for their affinity towards Chromium (VI). Sulphuric acid generated bio-char of stems of Averrhoa corambola plant was identified to be effective.

\section{Plant Description}

Averrhoa carambola is a small shrub that belongs to Oxalidaceae family of the plant kingdom. It grows to a height of about 10 meters. It is well grown in tropical conditions, especially in Southeast Asia. It yields fruits that are edible and possess medicinal values.

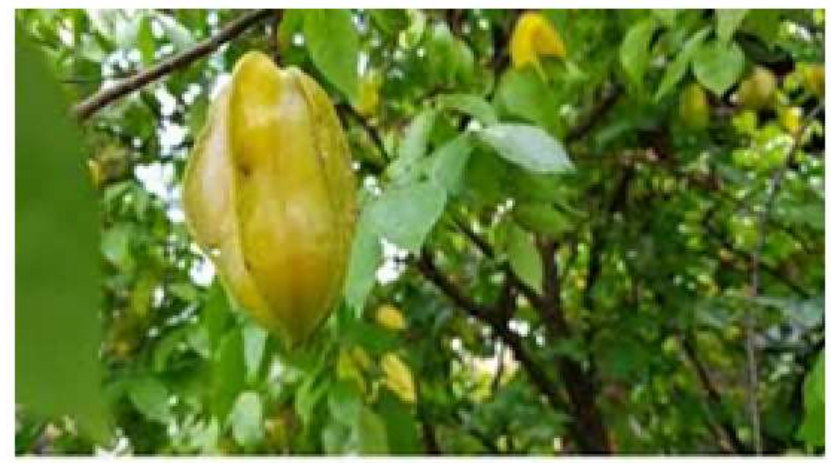

Fig.-1: Averrhoa carambola Plant showing Affinity for $\mathrm{Cr}(\mathrm{VI})$

\section{Preparation of Sulphuric Acid Activated Carbon}

Stems of Averrhoa carambola plant were cut into small pieces and half-dried under the Sun-light. The pieces were submerged in Conc. $\mathrm{H}_{2} \mathrm{SO}_{4}$ for 2 days. It was further digested in a round-bottomed flask using a condenser for 1 hour. Then the material was carbonized.

Thus synthesized bio-char was filtered. It was washed thoroughly with distilled water until the washings were neutral. Then the bio-char was dried at $110^{\circ} \mathrm{C}$ for 2 hours. It was ground in mortar and pestle for reducing the particle size. It was sieved through a $75 \mu \mathrm{m}$ ASTM mesh. This Sulphuric acid generated Biochar from Stems of Averrhoa carambola plant was named as SBCSAC. It is investigated for its sorption characteristics. This is employed as an adsorbent in the present investigation.

\section{Reagents and Chemicals}

Chemicals used were of Analytical Grade. $500 \mathrm{ppm}$ Chromate stock solution was prepared. It was diluted as per need. $0.25 \%$ of Diphenyl carbazide in $50 \%$ of acetone and $6 \mathrm{~N} \mathrm{H}_{2} \mathrm{SO}_{4}$ were used.

\section{Method}

Investigations were made through Batch Modes. ${ }^{9,10,31}$ Synthetic simulated waters of different concentrations of $\mathrm{Cr}$ were prepared for the present investigation to evaluate different parameters.

\section{General Procedure}

$100 \mathrm{ml}$ of Chromium (VI) solutions of different concentrations were taken into $250 \mathrm{ml}$ Iodine Flasks. To each flask, weighed quantities of SBCSAC were added. Initial $\mathrm{pHs}$ were adjusted using dil $\mathrm{HCl}$ or $\mathrm{NaOH}$. 
RASĀYAN J. Chem.

Vol. 13 | No. 4 |2490-2497| October - December | 2020

The flasks were shaken in a Mechanical shaker at $300 \mathrm{rpm}$ for the required time. Then the contents in the flask were filtered. The filtrates were assayed for residual Chromium (VI). .Diphenyl Carbazide Spectrophotometric method was used to estimate the residual Chromium as described by Arthur I. Vogle. ${ }^{32}$ The influence of $\mathrm{pH}$ (initial), time of equilibration, concentration of SBCSAC, initial $\mathrm{Cr}(\mathrm{VI})$ concentration and temperature on the sorption of $\mathrm{Cr}(\mathrm{VI})$ were investigated. For this, the general procedure described above was adopted by varying the targeted parameter while maintaining others at constant (optimum) values. Further, after establishing the optimum conditions of extraction, the possible interference of co-ions (five folds) was investigated. Regeneration and applications were also made. The results are presented in Figs.-2 to 8; Tables-1 and 2.

\section{Optimization of Extraction Conditions}

\section{RESULTS AND DISCUSSION}

Factors affecting the extraction were optimized for the maximum possible Chromium (VI) removal. The investigation results are presented hereunder.

\section{Initial pH}

By varying the initial $\mathrm{pH}$, the extraction was studied using Chromium (VI) solution of concentration 25 $\mathrm{ppm}$. The other conditions were kept constant: SBCSAC: $0.1 \mathrm{~g} / 100 \mathrm{ml}$; equilibrium time: $60 \mathrm{~min}$; rpm: 300 and temp. $303 \mathrm{~K}$. The observations are depicted in Fig.-2. There is a spectacular dependence of extraction on the $\mathrm{pH}$ of the solution. With the increase in $\mathrm{pH}$, extraction of Chromium (VI) falls.

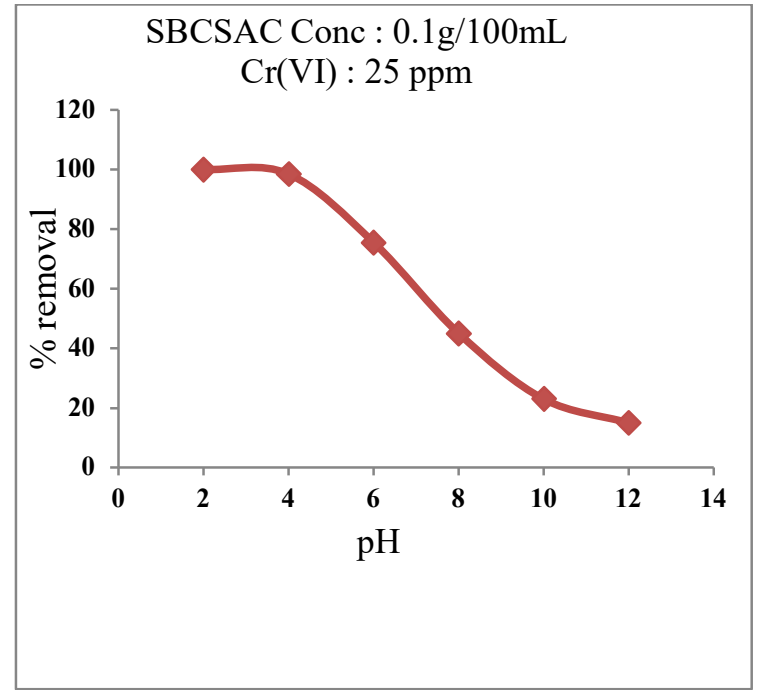

Fig.-2: pH Vs \% Cr(VI) Removal

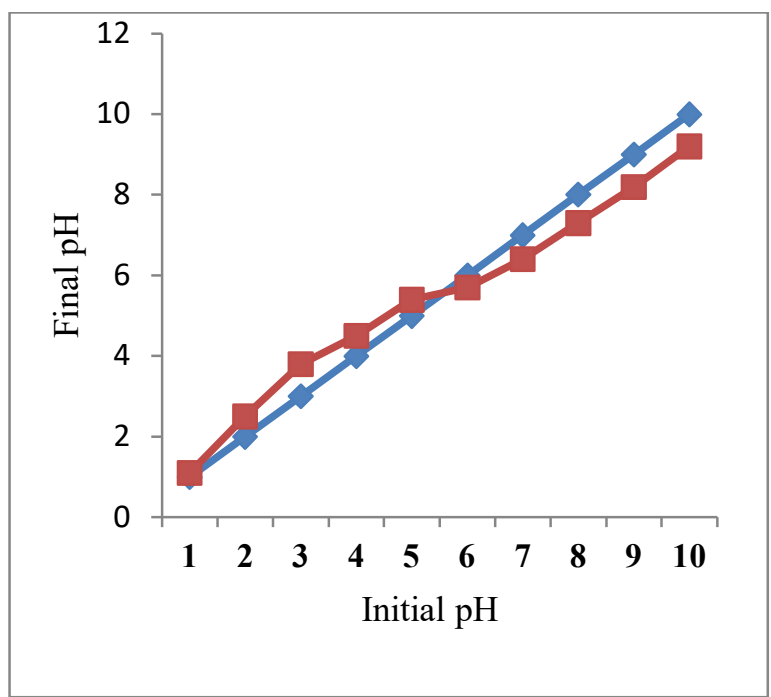

Fig.-3: $\mathrm{pH}_{\mathrm{ZPC}}$ Evaluation for SBCSAC

$100.0 \%$ removal of $\mathrm{Cr}$ is noticed at $\mathrm{pH}: 2$. At $\mathrm{pH} 4, \%$ removal is 98.5 ; at $\mathrm{pH}: 6: 75.5 \%$; at $\mathrm{pH}: 8: 45.0 \%$; at $\mathrm{pH}: 10: 23.0 \%$; and at $\mathrm{pH}: 12: 15.0 \%$.

These findings can be explained from the viewpoint of pHzpc of SBCSAC. pHzpc was evaluated for the adsorbent, Fig.-3. The value is 5.5. Above this pHzpc, the surface has a negative charge. It is due to the dissociation of functional groups on the surface of SBCSAC. Below this value, the dissociation is less favored. At low $\mathrm{pHs}$, the surface of SBCSAC possesses a positive charge. So, Chromium (VI) being anion is attracted towards the surface of SBCSAC only at low $\mathrm{pHs}$. At $\mathrm{pHs}$ above pHzero, the negative charge on SBCSAC repels negatively charged Chromium (VI) species. So adsorption is less favored. The optimum $\mathrm{pH}$ is 2. At this $\mathrm{pH}$, complete removal of Chromium (VI) was noticed.

\section{Equilibration Time}

With sorbent dosage at $0.1 \mathrm{~g} / 200 \mathrm{ml}, 25 \mathrm{ppm}$ Chromium(VI) solution was equilibrated at different times; the rpm is 300 and temperature is: $303 \mathrm{~K}$. The findings are plotted in Fig.-4. 
RASĀYAN $J$. Chem.

Vol. 13 | No. 4 |2490-2497| October - December | 2020

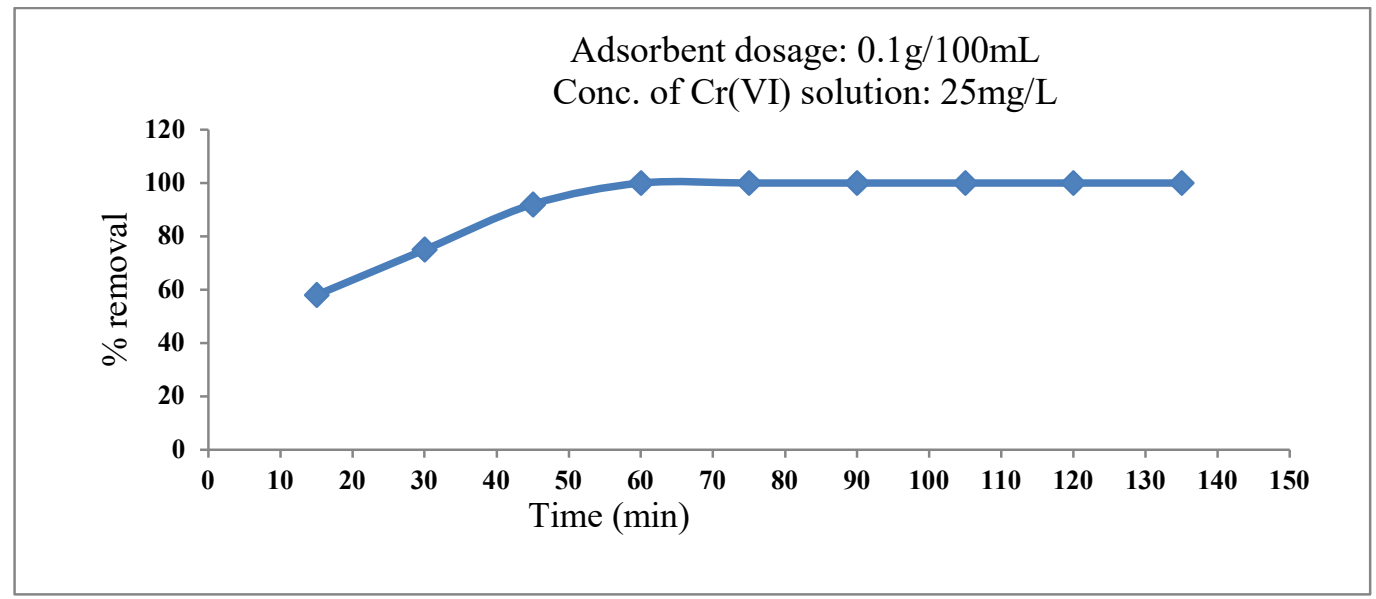

Fig.-4: Time Vs \% Cr(VI) Removal

With the increase of time of equilibration, \% removal is linearly (nearly) increased up to 60 minutes. After that, a study state is reached. At 15 minutes, $58.0 \%$ of removal is noticed; at 30 minutes: $75.0 \%$; at 45 minutes : $92.0 \%$; and $100.0 \%$ at 60 min or above. The minimum time needed for complete removal of Chromium (VI) is 60 minutes.

\section{SBCSAC Concentration}

To assess the optimum SBCSAC concentration, definite amounts of SBCSAC ranging from $25 \mathrm{mg}$ to 250 $\mathrm{mg}$ were added to $100 \mathrm{ml}$ of $25 \mathrm{ppm}$ Chromium (VI) solution. The resulting mixture's $\mathrm{pH}$ was adjusted to 2. Then the solutions were agitated for 60 minutes at $300 \mathrm{rpm}$ and $303 \mathrm{~K}$.

The solutions were filtered and the residual Chromium (VI) was assessed. The findings are plotted in Fig.5. It is seen from the figure, \% removal is almost linearly increased with the rise in SBCSAC concentration up to $100 \mathrm{mg} / 100 \mathrm{ml}$. After that, steady state results. With SBCSAC concentration of $25 \mathrm{mg} / 100 \mathrm{ml}$, the \% removal is: $51.0 \%$; with $50 \mathrm{mg} / 100 \mathrm{ml}: 68.0 \%$; with $75 \mathrm{mg} / 100 \mathrm{ml}: 85.6 \%$ and with $100 \mathrm{mg} / 100 \mathrm{ml}$ or above: $100 \%$. So at optimum $100 \mathrm{mg} / 100 \mathrm{ml}$, complete removal of Chromium (VI) is noticed. SBCSAC adsorption capacity is: $40 \mathrm{mg} / \mathrm{g}$. This is highest than many reported adsorbents.

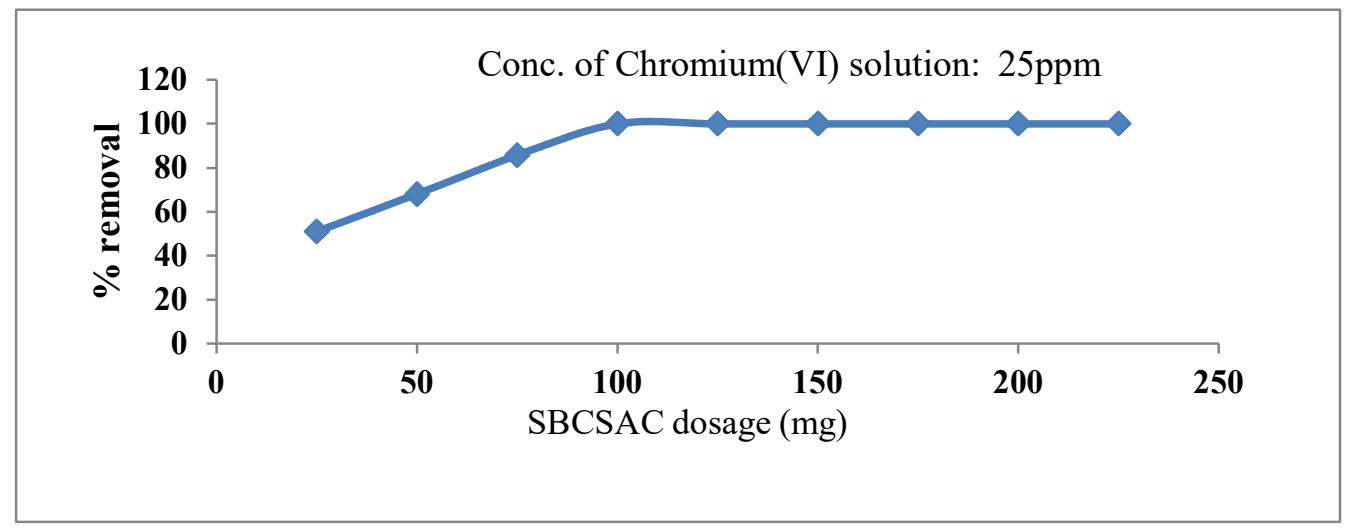

\section{Initial Cr-concentration}

Fig.-5: Dosage Vs Cr(VI) Removal

$0.1 \mathrm{~g}$ of SBCSAC was added to $100 \mathrm{ml}$ of different Chromium (VI) concentrations ranging from $20 \mathrm{ppm}$ to $100 \mathrm{ppm}$. The initial $\mathrm{pH}$ of these solutions was adjusted to 2 . Then the solutions were equilibrated for 60 minutes at $300 \mathrm{rpm}$ and at $303 \mathrm{~K}$. The solutions were filtered. Residual Chromium (VI) was assessed. The results were plotted in Fig.-6.

With the raise in initial concentration, \% removal is decreased; below $25 \mathrm{ppm}: 100 \% ; 30 \mathrm{ppm}: 90.0 \% ; 40$ ppm : $73.0 \% ; 50$ ppm : $61.0 \% ; 60$ ppm: $51.0 \% ; 70$ ppm : $40.0 \% ; 80$ ppm: $35.0 \%$ and 90 ppm : $30.0 \%$. 
RASĀYAN J. Chem.

Vol. 13 | No. 4 |2490-2497| October - December | 2020

All these investigations were made using $0.1 \mathrm{~g} / 100 \mathrm{ml}$ of SBCSAC. So, for a fixed adsorbent, the active sites are fixed. When the concentration of Chromium (VI) is low, active sites available per molecule of Chromium(VI) are more. With the rise in concentration, many of the active sites are blocked or engaged and hence, the effective availability of free sites is less. So, the \% removal is decreased with the enhancement in the Chromium (VI) concentration.

\section{Interferences of Co-ions}

The effect of fivefold excess of Co-ions on \% removal is investigated and the results are presented in Fig.-7(a) and 7(b).

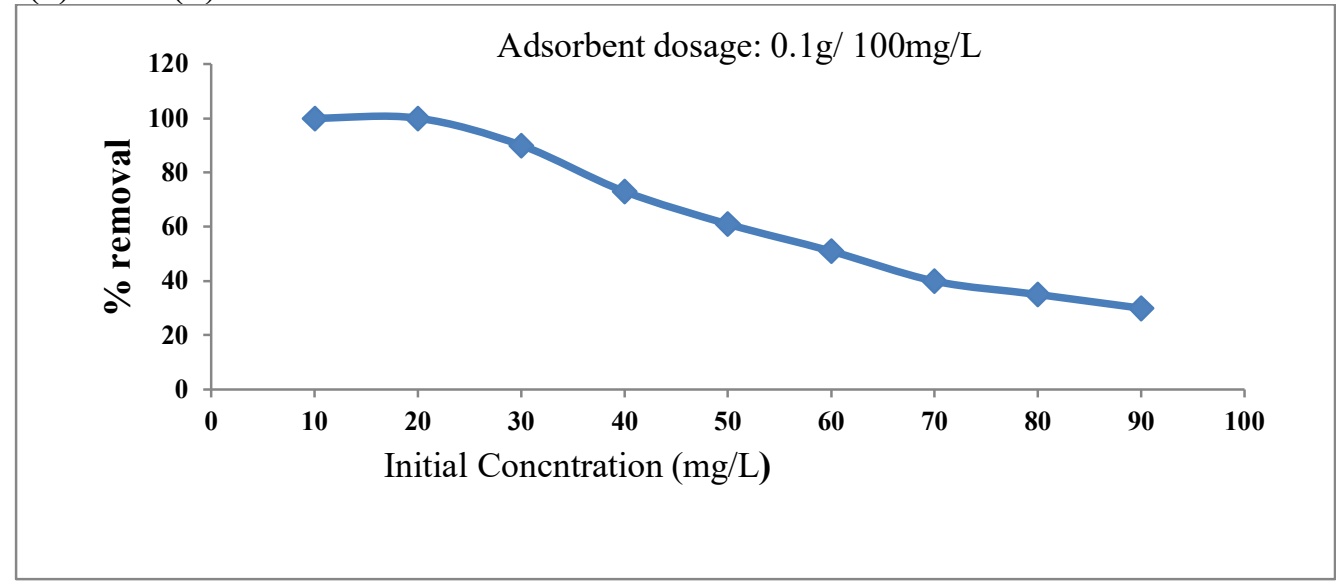

Fig.-6: Initial Concentration Vs \% Cr(VI) Removal

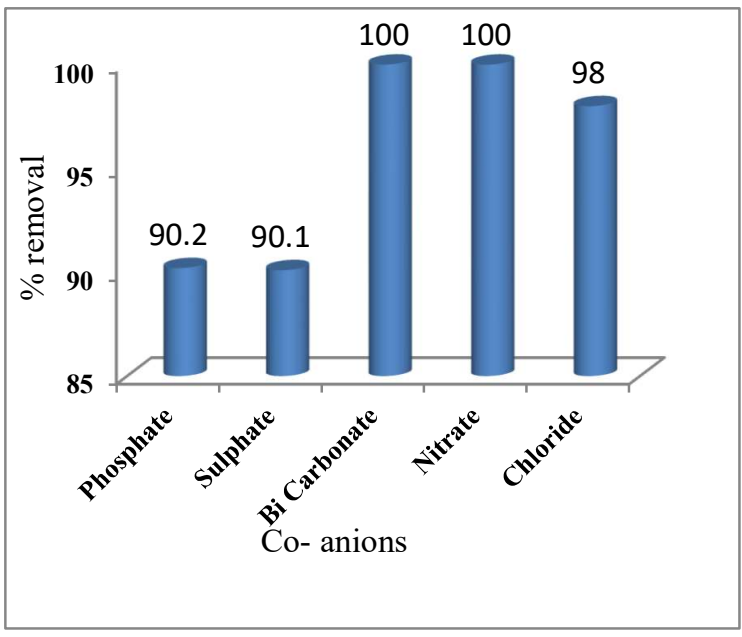

Fig.-7a: Co- anions Interference

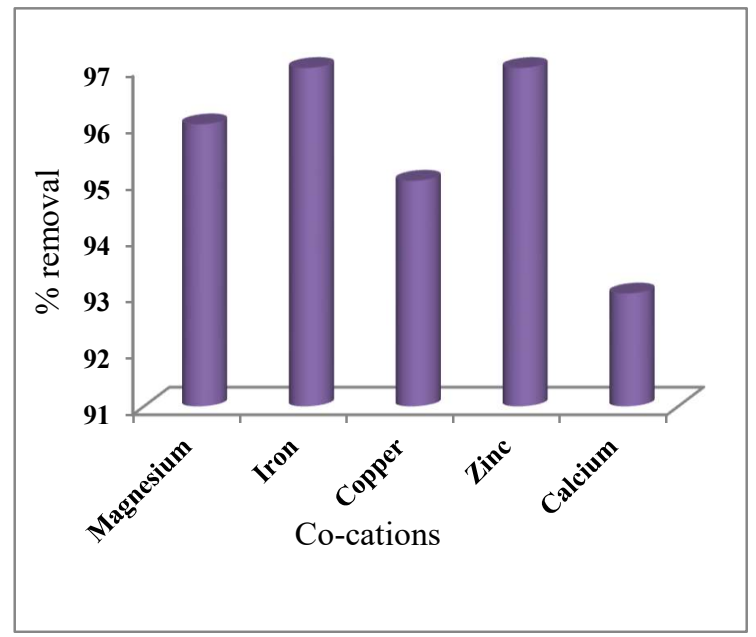

Fig.-7b: Co- cations Interference

Interference caused by generally co-existing ions in the water on the percentage removal of Chromium (VI) was assessed. For this, simulated solutions having fivefold excess of co-ions were prepared. They were treated with the $0.1 \mathrm{~g} / 100 \mathrm{ml}$ of SBCSAC at $\mathrm{pH}: 2$ for 60 minutes at $300 \mathrm{rpm}$ and $303 \mathrm{~K}$. The solutions were filtered and the filtrate was estimated for residual Chromium (VI). The results were plotted in Fig $7 \mathrm{a}$ and b. Nitrates, Bicarbonates and Chlorides show no interference. Phosphate and Sulphate interfere to a less extent. Co-cations investigated show marginal interference.

\section{Regenerating and Reusing of SBCSAC}

One of the important features to be assessed in using these bio-adsorbents is their reuse after regeneration. Regeneration is a treatment to be given to spent adsorbents to regain their adsorption ability. So spent SBCSAC was treated with various solutions of acids, bases and salts. A definite quantity of spent SBCSAC 
RASĀYAN $J$. Chem.

Vol. 13 | No. 4 |2490-2497| October - December | 2020

was treated with these diverse solutions and agitated for one hour. Then the solutions were filtered. SBCSAC was washed repeatedly with distilled water until the washings were neutral to the litmus. Then SBCSAC was dried at $105^{\circ} \mathrm{C}$, cooled and reused as adsorbent. It was found that the $0.1 \mathrm{~N} \mathrm{NaOH}$ solution was an effective solvent for regeneration. These regeneration steps are repeated. The number of recycles Vs \% removal of $\mathrm{Cr}$ is plotted in Fig 8. Percentage of Cr-removal is found to be: 100 for first regeneration; 98.5 for a second; 97.8 for third; 92.1 for fourth; 89.5 for fifth; 70.1 for sixth and 60.0 for seventh. Hence, SBCSAC is retaining its capacity until the fourth regeneration with marginal loss.

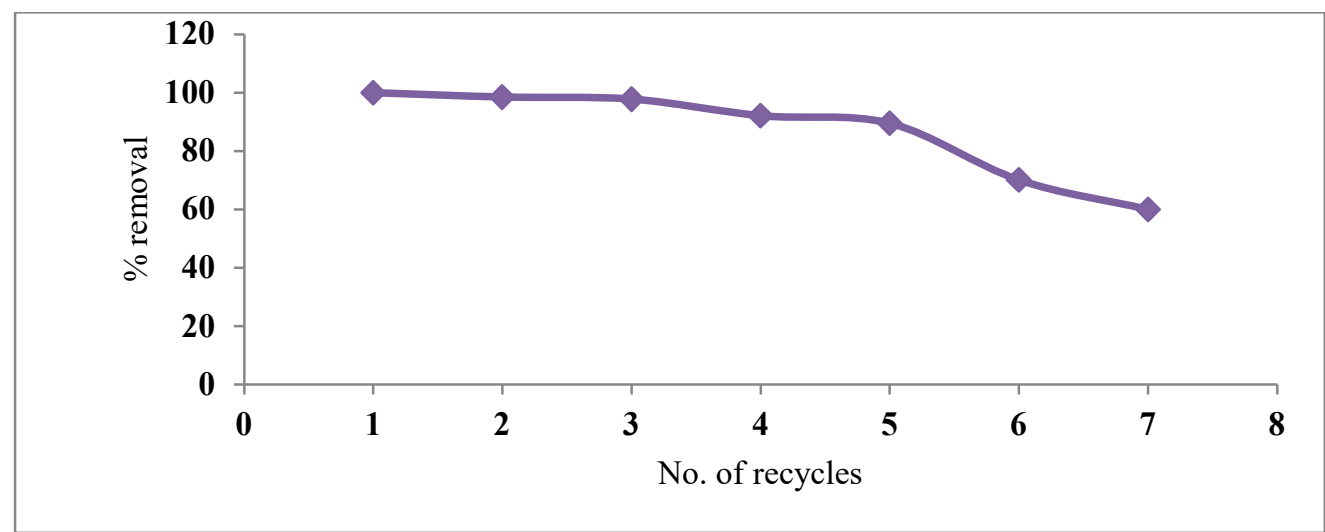

\section{Applications}

Fig.-8: Regenerations Vs \% Removal

SBCSAC was evaluated to control the Chromium pollution in effluents from industries. Samples were collected from various industries. For $100 \mathrm{ml}$ of each sample, $0.1 \mathrm{~g}$ of SBCSAC was added. $\mathrm{pH}$ was adjusted to 2 . The solution was agitated for 60 minutes at $300 \mathrm{rpm}$ and $303 \mathrm{~K}$. The solution was filtered and assayed for residual Chromium (VI) content. Experiments were repeated thrice. The average values were noted in Table-1.

Table-1: Chromium (VI) Removal from Industry Effluents Samples

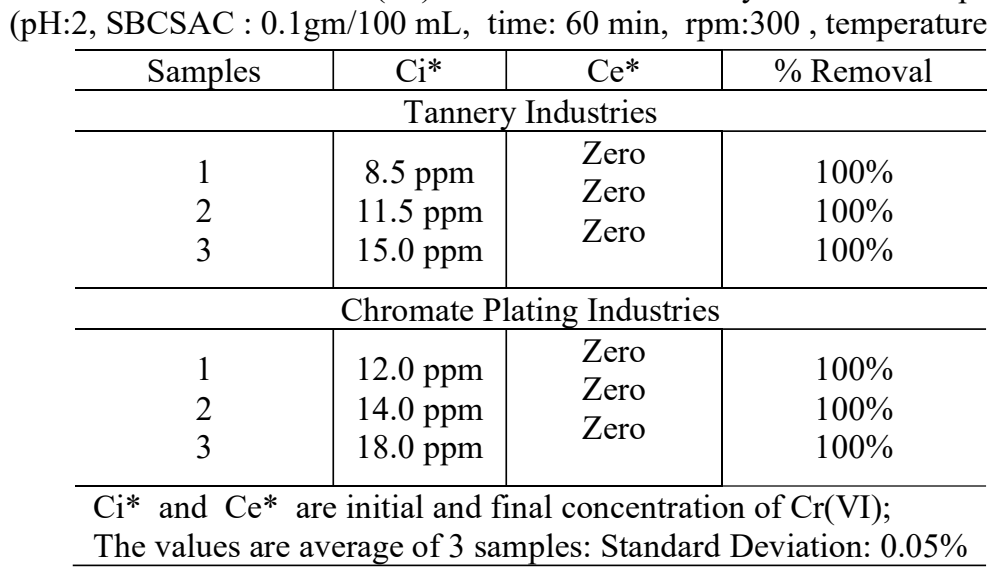

\section{Comparative Study with the Previous Works}

The Chromium-sorption capacity of SBCSAC is compared with the good bio-adsorbents reported. Table-2 is the comparison table. It may be concluded that SBCSAC has sorption capacity more than many reported. Further, SBCSAC is derived from a plant that is grown well in South East Asian Countries.

Table-2: Adsorption Capacities Comparison

\begin{tabular}{c|c|c|c|c|c}
\hline S. No. & Adsorbent & $\mathrm{pH}$ & $\begin{array}{c}\text { Ci. Of Cr(VI) } \\
\text { (in ppm) }\end{array}$ & $\begin{array}{c}\text { Adsorption Capacity } \\
\text { for Cr (VI) }\end{array}$ & References \\
\hline 1 & $\begin{array}{c}\text { Barks Of Ziziphus } \\
\text { mauritiana plant }\end{array}$ & 2 & 20.0 & $18.8 \mathrm{mg} / \mathrm{g}$ & 26 \\
\hline
\end{tabular}


RASĀYAN J. Chem.

Vol. 13 | No. 4 |2490-2497| October - December | 2020

\begin{tabular}{|c|c|c|c|c|c|}
\hline 2 & $\begin{array}{l}\text { Active carbon derived } \\
\text { from Lantana camara } \\
\text { plant }\end{array}$ & 2 & 50.0 . & $26.25 \mathrm{mg} / \mathrm{g}$ & 17 \\
\hline 3 & Saw dust of Coconut tree & 3 & 20.0 & $3.6 \mathrm{mg} / \mathrm{g}$ & 33 \\
\hline 4 & $\begin{array}{c}\text { Leaves of Salvadora } \\
\text { persica plantk }\end{array}$ & 2 & 50.0 & $\begin{array}{l}16.2 \mathrm{mg} / \mathrm{g} \text { (leaves) } \\
22.9 \mathrm{mg} / \mathrm{g} \text { (ashes) }\end{array}$ & 29 \\
\hline 5 & $\begin{array}{l}\text { Leaves of Caesalpinia } \\
\text { bonduc plant }\end{array}$ & 2 & 50.0 & $\begin{array}{l}12.7 \mathrm{mg} / \mathrm{g} \text { (leaves) } \\
\text { and } 19.6 \mathrm{mg} / \mathrm{g} \text { (ash) }\end{array}$ & 29 \\
\hline 6 & Spent coffee grounds & & 50.0 & $22.75 \mathrm{mg} / \mathrm{g}$ & 3 \\
\hline 7 & $\begin{array}{l}\text { Active carbon of Coconut } \\
\text { shell }\end{array}$ & 4 & 25.0 & $20.0 \mathrm{mg} / \mathrm{g}$ & 34 \\
\hline 8 & Saw dust of beech tree & 1 & 200.0 & $16.0 \mathrm{mg} / \mathrm{g}$ & 36 \\
\hline 9 & bagasse of Sugar cane & 2 & 500.0 & $13.4 \mathrm{mg} / \mathrm{g}$ & 35 \\
\hline 10. & $\begin{array}{c}\text { Phoenix sylvestris seeds } \\
\text { powder (PSSP) }\end{array}$ & 2 & 20 & $22.5 \mathrm{mg} / \mathrm{g}$ & 28 \\
\hline 11. & $\begin{array}{c}\text { Sulphuric acid generated } \\
\text { bio-char from stems of } \\
\text { Averrhoa carambola plant } \\
\text { (SbCSAC) }\end{array}$ & 2 & 25.0 & $40 \mathrm{mg} / \mathrm{g}$ & Present work \\
\hline
\end{tabular}

\section{CONCLUSION}

- Stems of Averrhoa carambola plant are used as a precursor for generating bio-char.

- Sulphuric acid generated bio-char of stems of Averrhoa carambola plant (SBCSAC) is effective for the removal of Chromium (VI) from water.

- Complete removal of Chromium (VI) is observed in the $\mathrm{pH}$ range: 2 to 4 from $25 \mathrm{ppm}$ Chromium (VI) solution. The optimum equilibration time is one hour and sorbent dosage is $0.1 \mathrm{~g} / 100 \mathrm{ml}$ of SBCSAC. $300 \mathrm{rpm}$ is used at room temperature of $303 \mathrm{~K}$.

- The adsorption capacity of SBCSAC is $40 \mathrm{mg} / \mathrm{g}$. It is higher than many sorbents reported.

- The interference of co-ions is marginal.

- Spent SBCSAC can be claimed back by treating with $0.1 \mathrm{~N} \mathrm{NaOH}$. Thus regenerated SBCSAC can be reused. Until four cycles of regenerations, only a marginal loss of adsorption capacity for Chromium (VI) is observed.

- SBCSAC is effectively applied to remove completely Chromium (VI) from samples collected from industrial effluents.

\section{ACKNOWLEDGEMENT}

The authors thank K L University authorities for providing facilities for this research work.

\section{REFERENCES}

1. S. Lenore Clesceri, E. Arnold E. Greenberg and Andrew D. Easton (Editors), Standard Methods for the Examination of Water and Wastewater, 20th Edition, American Public Health Association, pp. 365 (1998).

2. R. Mehra, and M. Juneja, Indian Journal of Biochemistry and Biophysics, 40, 131(2003).

3. G.V Krishna Mohan, A. Naga Babu, K. Kalpana and K. Ravindhranath, International Journal of. Environmental Science Technology, 16(1), 101(2019), DOI:10.1007/s13762-017-1593-7

4. US Department of Health and Human Services, 1991, Profile for Chromium, Public Health Service Agency for Toxic substances and Diseases, Washington, DC (1991).

5. Z. Kowalski, Journal of. Hazardous Materials, 37,137(1994), DOI:10.1016/0304-3894(94)85042-9

6. R. Mehra, and M. Juneja, Indian Journal of Biochemistry and Biophysics, 40, 131(2003)

7. S. Ravulapalli and K. Ravindhranath, Journal of Environmental Chemical Engineering,6 (4), 4298 (2018), DOI:10.1016/j.jece.2018.06.033

8. E. Parameswari E., A. Lakshmanan and T. Thilagavathi, Australian Journal of Basic and Applied Sciences, 3(2), 1363 (2009). 
RASĀYAN J. Chem.

Vol. 13 | No. 4 |2490-2497| October - December | 2020

9. Metcalf and Eddy (Editor), Wastewater Engineering: Treatment of Reuse. 4th. Ed., McGraw Hill Co., New York (2003).

10. Gerard Kiely., Environmental Engineering, McGraw-hall International Editions (1998).

11. R.H. Krishna Reddy, N. Naga Malleswara Rao, J. V. Suman Krishna, K. Ravindhranath, Der Pharma Chemica, 8(10), 47 (2016).

12. S.S. Chen, C.Y. Cheng, Li,C.W., P.H. Chai and Y.M. Chang, J. Hazardous Materials, 142, 362 (2006), DOI:10.1016/j.jhazmat.2006.08.029

13. Shiv Kumar Verma, Vinita Khandegar and Anil. K. Saroha, Journal of Hazardous, Toxic, and Radioactive Waste, 17(2), 146(2013), DOI:10.1061/(ASCE)HZ.2153-5515.0000170

14. S. A. Cavaco, S. Fernandes, M.M. Quina and L. Ferreira, Journal of Hazardous Materials, 144, 634 (2007), DOI:10.1016/j.jhazmat.2007.01.087

15. M.T. Ahmed, S. Taha, T. Chaabane, D. Akretche, R. Maachi and G. Dorange, Desalination, 200, 419 (2006), DOI:10.1016/j.desal.2006.03.354

16. B. Preetha and T. Viruthagiri, Biochemical. Engineering Journal, 34, 131(2007), DOI: 10.1016/j.bej.2006.11.022

17. Sujitha Ravulapalli and Ravindhranath Kunta, Water Science and Technology, 78(6), 1377 (2018), DOI: 10.2166/wst.2018.413

18. Imran Ali and V. K. Gupta, Nature, 1, 2661(2006), DOI:10.1038/nprot.2006.370

19. Imran Ali, Separation and Purification Reviews, 39, 95(2010), DOI:10.1080/15422119.2010.527802

20. D. Mohan, D., K.P. Singh, and V. K. Singh, Industrial. Engineering Chemical. Research, 44(4), 1027 (2005), DOI:10.1021/ie0400898

21. G. N. Manju and T.S. Anirudhan, Indian Journal of Environmental Health, 39, 289 (1997).

22. V. Sarin and K.K. Pant, Bioresource Technology, 97, 15(2006), DOI:10.1016/j.biortech.2005.02.010

23. L.J. Yu, S.S. Shukla, K.L. Dorris, A. Shukla and J.L. Margrave, Journal of Hazardous Materials, 100, 53(2003), DOI:10.1016/s0304-3894(03)00008-6

24. T. Karthikeyan, S. Rajgopal and L.R. Miranda, Journal of Hazardous Materials, 124(1-3), 192, (2005), DOI:10.1016/j.jhazmat.2005.05.003

25. Seyed Mahmoud Mehdinia, Khalilollah Moeinian and Tayyabeh Rastgoo, Iranica Journal of Energy \& Environment, 5(2), 218(2014), DOI:10.5829/idosi.ijee.2014.05.02.15

26. O. Sree Devi. and K. Ravindhranath, Indian Journal of Environment Protection, 32(11), 943(2012).

27. K. Venkata Pravalika, P. Janaki Sriram, P. Karunasri Meghana and K. Ravindhranath, Rasayan Journal of Chemistry, 11(4), 1750(2018), DOI:10.31788/RJC.2018.1145048

28. P. Karunasri Meghana, K. Venkata Pravalika, P. Janaki Sriram and K. Ravindhranath, Asian Journal of Chemistry, 31(6), 1327(2019), DOI:10.14233/ajchem.2019.21760

29. Y. Hanumantha Rao and K. Ravindhranath, Rasayan Journal of Chemistry, 10(4), 1104(2017), DOI: 10.7324/RJC.2017.1041829

30. A. Naga Babu, G.V. Krishna Mohan and K. Ravindhranath, International Journal of ChemTech Research, 9 (3), 506(2016).

31. R. K. Trivedy, Pollution Management in Industries, Environmental Publications, Karad, India 1979.

32. Arthur I. Vogle., A text book of Quantitative Inorganic Analysis including elementary Instrumental Analysis , 1961, 3rd Ed., ELBS. p.792.

33. K. Selvi, S. Pattabhi and K. Kadirvelu, Bioresources Technology., 80, 87(2001), DOI:10.1016/s0960$8524(01) 00068-2$

34. G. Alaerts, V. Jitjaturunt and P. Kelderman, Water Science Technology, 21, 1701 (1989).

35. D. Sharma and C. Forster, Bioresource Technology, 47, 257(1994), DOI:10.1016/09608524(94)90189-9

36. F. Acar and E. Malkoc, Bioresource Technology, 94, 13(2004), DOI:10.1016/j.biortech.2003.10.032

[RJC-5908/2020] 